\title{
Something Brewing in Boston: A Study of Forward Integration in American Breweries at the Turn of the Twentieth Century
}

\section{ZACHARY NOWAK}

In this article, I describe the partial forward integration of turn-of-the-twentieth-century Boston breweries. I argue that both brewers and saloonkeepers used the fluid market in capital lending as a lever of power. An analysis of the minutes of three breweries and their loan records, covering more than ten years, reveals that saloonkeepers were often delinquent in repaying their annual loans and brewery owners only infrequently threatened to call the loans. Using the structureconduct-performance paradigm, I suggest that the particular conditions in Boston (a limited number of saloon licenses and a geographical position that precluded long-distance shipping of beer) gave the saloonkeepers much greater leverage in the so-called "tied system." Brewers used vertical restraints but, because of obligations to British owners, did not fully forward integrate by buying saloon property, as brewers did in the United Kingdom.

(C) The Author 2017. Published by Cambridge University Press on behalf of the Business History Conference.

doi:10.1017/eso.2016.59

Published online January 18, 2017

ZACHARY NOWAK is a doctoral candidate in American Studies at Harvard University, as well as the associate director for the Food \& Sustainability Studies Program at the Umbra Institute.

This article began as a paper at the History of Capitalism seminar, led by Christine Desan and Sven Beckert. The author would like to thank the members of the seminar, as well as Rudi Batzell, Joyce Chaplin, Charles Petersen, Dan Hinchen, Michael Reiskind, Luke Willert, Caitlin Rosenthal, Bradley M. Jones, Tim Mahoney, Laura Linard, and Victor J. Tremblay, as well as the Shields-Haffenreffer family, the Massachusetts Historical Society, the Harvard Baker Library, and the Historic New England for their invaluable contributions to this article. The extensive, thoughtful feedback of this journal's editor, Andrew Popp, and the three anonymous reviewers was also absolutely fundamental. E-mail: znowak@fas.harvard.edu 
A photograph taken in Boston in 1901 shows P. J. Hagerty's saloon in Boston (see figure 1). Hagerty's name is just above the door, but it is dwarfed and significantly upstaged by the Roessle Brewery's two signs. It is unclear from the photograph what the relation of the two men pictured in it is to the saloon; the man in a barkeeper outfit may be Hagerty. However, the relationship between the saloon and the brewery seems clear: the obligation to put the Roessle's signs over his saloon-and probably to serve only Roessle products on tapwas likely part of a contract Hagerty had to sign in order to receive a loan. This loan tied the saloonkeeper to the brewery, one of the variations of a system that was referred to as the "tied system." The Roessle Brewery's account books show that between 1897 and 1900, Hagerty received loans for a total of nearly $\$ 4,000$, and that he made regular payments until his loan was paid off in September 1900. Hagerty, as will be seen in this article, was a statistical outlier because most saloonkeepers of the era put up very little collateral and frequently did not repay their loans on a regular schedule, if they repaid the loans at all. Nevertheless, in the records of the three breweries examined for this article (the Suffolk, the Boylston [also known as the Haffenreffer], and the Roessle), the brewery owners continued to loan large sums of money. Indeed, in the years for which records exist (except for 1902), these three breweries loaned more money to saloonkeepers than was repaid.

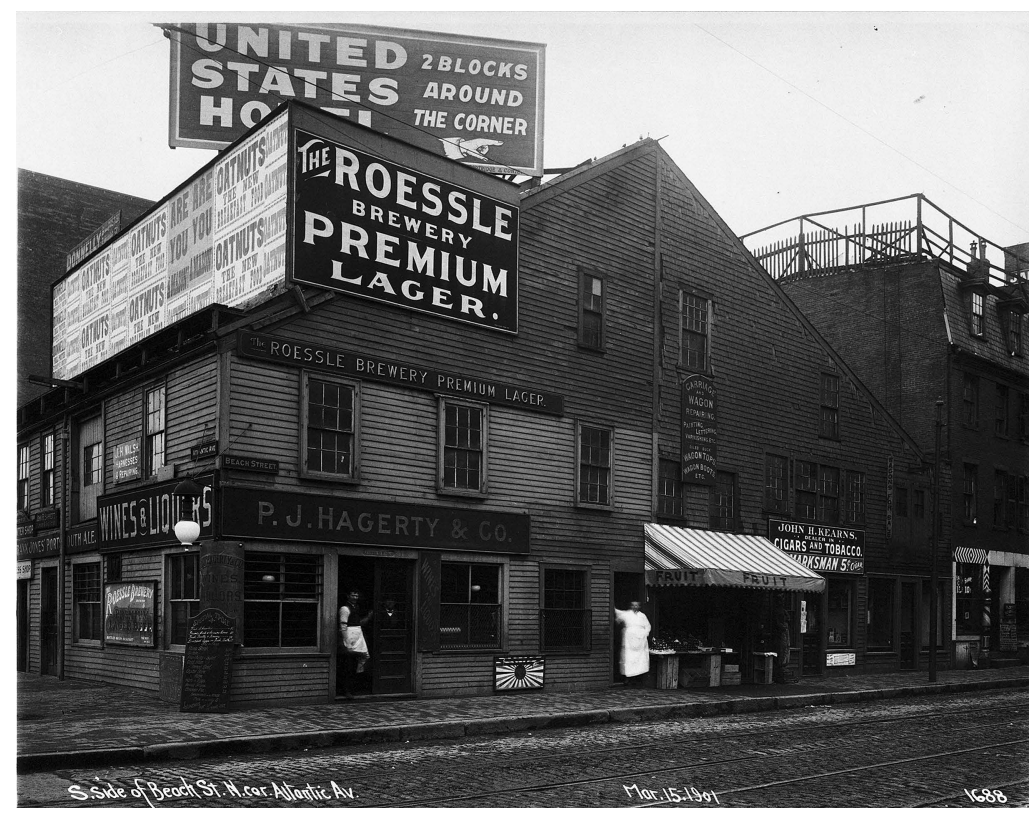

Figure 1 P. J. Hagerty's Boston saloon on the south side of Beach Street, near the corner of Atlantic Avenue (courtesy of Historic New England). 
Why would these firms contract with deadbeat saloonkeepers rather than own and run the saloons directly? This article investigates the economics of forward integration in the brewery industry in Boston at the turn of the last century in order to answer this question. The underlying theoretical framework is the structure-conduct-performance (SCP) paradigm, which I use to examine the market environment in Boston in comparison to the British beer market. ${ }^{1}$ Boston's large number of consumers of beer (given its German and Irish immigrant populations), and its distance from major breweries in other large cities (such as New York and Philadelphia) and from the major shipping breweries of the Midwest, all contributed to a different strategy. I draw on Michael Porter's theory of strategy and Oliver Williamson's work on transaction costs to suggest why these American brewers' strategies of forward integration were so different than those of their British counterparts. ${ }^{2}$ Using data from three turn-of-the-twentiethcentury Boston breweries, I argue that what seems to be an irrational and unsustainable strategy (the ever-increasing lending, shown in table 1) was actually a transaction cost necessary for the breweries to maintain their access to consumers through an artificially limited number of retail outlets. Capital lending was a lever of power used to tie saloonkeepers to their brewer-suppliers, yet the competitive lending market (in the context of a legislatively restricted retail market) also meant that saloonkeepers had a certain power vis-à-vis the breweries. Debt was-as everywhere-a lever of power. It was, however, a smaller lever in Boston than elsewhere; it was large enough to move a keg of beer but not much larger.

Table 1 Data for amalgamated loans and repayments

\begin{tabular}{lccc}
\hline Year & Loans Made & Loans Repaid & Net \\
\hline 1897 & $\$ 28,943$ & $\$ 13,015$ & $(-\$ 15,928)$ \\
1898 & $\$ 81,705$ & $\$ 67,733$ & $(-\$ 13,972)$ \\
1899 & $\$ 125,225$ & $\$ 93,395$ & $(-\$ 31,830)$ \\
1900 & $\$ 118,217$ & $\$ 89,201$ & $(-\$ 29,016)$ \\
1901 & $\$ 83,836$ & $\$ 76,281$ & $(-\$ 7,555)$ \\
1902 & $\$ 55,473$ & $\$ 75,096$ & $\$ 19,623$ \\
1903 & $\$ 95,836$ & $\$ 58,584$ & $(-\$ 37,252)$ \\
\hline
\end{tabular}

Note: This data is for the available years for the three breweries discussed in this article. The year 1902, in which a strike occurred, was the only one in which breweries had a positive net on loans.

1. J. S. Bain's 1959 work laid the foundation for Frederic Scherer's research and the later development of the SCP paradigm. See Bain, Industrial Organization.

2. Porter, Dynamic Theory of Strategy; Williamson, "Transaction Cost Economics." 


\section{The Archive: Entries and Silences}

In 1790 American physician and reformer Benjamin Rush published a pamphlet on temperance that provided a "thermometer" of beverages, calibrated to their effect on morals. "Small” (low-level alcohol) beer led to happiness, while porter and strong beer gave "nourishment when taken only at meals and in moderate quantities." 3 By the 1850s, even this grudging acceptance of stronger beer had evaporated to some degree, with Maine leading the way with its total prohibition of alcohol in 1851. Other states, including Massachusetts, passed laws that allowed individual municipalities to restrict alcohol, although the temperance movement succeeded in getting the Eighteenth Amendment passed in 1919, which outlawed wholesale the production and sale of most alcoholic beverages.

Prohibition, as the failed experiment in extreme temperance is known, led to the closure of hundreds of American breweries. ${ }^{4}$ Although repeal came in 1933 with the Twenty-First Amendment, the fourteen-year period created many archival silences as breweries closed and their records were lost. Only two Boston breweries survived Prohibition, one of which was the Haffenreffer Brewing Company. ${ }^{5}$ It limped through the post-World War II reordering of the American beer market and finally closed in 1964. While I will use other archival records to more fully describe the marketplace that saloonkeepers and breweries occupied in Boston's pre-Prohibition economy, the documents in the Haffenreffer collection constitute my primary source. The bulk of the documents in the collection are dated between 1896 and 1903. In 1890 an English syndicate bought three above-mentioned Boston-area breweries: the Suffolk, the Boylston, and the Roessle. Because the Meetings and Minutes books for the Committee of Management are records of all three breweries, they provide a broader picture than could be derived from the archives of just one company. ${ }^{6}$

Each month's minutes began with a series of statistical information, such as managers' reports on the number of barrels produced, amount

3. Rush, Inquiry, 12.

4. For a recent history of Prohibition, see McGirr, War on Alcohol.

5. Jamaica Plain Historical Society, "Boston's Lost Breweries," http://www. jphs.org/victorian/bostons-lost-breweries.html, 2006.

6. Although they are currently in the process of accession to the Harvard Baker Library, I had access to the documents during processing. The collection name is still to be determined, which is why I refer to the Haffenreffer Brewing Co. records in the Harvard Baker Business Library as the Haffenreffer Records. Their accession was made possible by a generous donation by the Haffenreffer-Shields family. 
of sales, pounds of hops and malt purchased, etc. Another important series of entries in this quantitative information were loans made to and repaid by saloonkeepers. Between October 1897 and November 1903 (the years for which there are Committee of Management minutes), there were 499 entries for loans made by the brewers to the saloonkeepers and almost 1,600 entries for loans repaid. Brewers would often make a yearly loan-usually in April, right before the saloonkeepers needed to pay for a new liquor licenseand the saloonkeepers would repay them slowly over the course of the year. That said, there were both small and large loans made throughout the year: the small loans to regular customers often had no notations and the larger ones to new saloonkeepers sometimes listed what security was given for the loan (such as promissory notes, mortgages, or life insurance policies).

In addition to this quantitative information, the minutes recorded conversations and even arguments between the three breweries' managers on the day-to-day management of the business, as well as pointed questions about finances from New York-based lawyer Samuel Untermyer, who represented the English parent company. Indeed, his presence forced the brewers to justify their decisions and added depth to the discussions. The text of these minutes allowed me to go beyond simple conclusions from the loan data to discuss the types of securities used by saloonkeepers and accepted by brewers for loans. This data-including discussions of other breweries, local liquor license regulations, federal taxation, and the 1902 brewery workers' strike-reveals the limits of the tied system, which is discussed below.

As Michel Rolph Trouillot observed, archives contain not only voices but also silences; the construction of the archive and the documents it contains encourage selective retrieval and allow only some stories to be told. ${ }^{7}$ From the pages of the Minutes, there is nearly no mention of brewery workers (for example, their salaries) or the dayto-day supply lists of saloonkeepers. Neither do they offer an idea of the percentage of saloons in Boston either tied or completely independent. The saloonkeepers that appear in these records are only those who owed money to the brewers. While I can piece together a few other details about P. J. Hagerty, most of what I know of him comes from the period when he owed Mr. Roessle money, not when he owned

7. Trouillot, Silencing the Past. Voce, the Italian word for a dictionary or accounting entry, also translates as "voice," which underlines the fact that archives, although written, contain much that was actually spoken. For more on this relationship, see Alessandro Portelli's classic essay, "What Makes Oral History Different." 
his saloon free and clear. These documents, then, did not allow me to tell the story of the brewery workers (my original intended subjects) and did not allow for a complete discussion of turn-of-the-twentiethcentury saloonkeepers. They did, however, permit some inferences about the bargaining power of saloonkeepers, their actions, and the conduct of their business partners-Boston brewery owners.

\section{The Tied System in the United Kingdom and the United States}

The structures of any market create both advantages and disadvantages for firms either to partially or fully forward integrate rather than to operate in a completely free spot market. In the UK brewery industry, owning retail outlets (called a first-order tie) meant that brewers had a guaranteed distribution network as well as more control over how house staff (or the tenant publican) treated customers, how the product (mainly keg beer) was maintained and presented, and how the outlet was furnished and maintained. ${ }^{8}$ Purchasing retail outlets was, however, capital-intensive and had obvious opportunity costs: the capital used to purchase, maintain, and possibly also staff these outlets was then unavailable for research and development, advertising, or other uses. The intermediate solution was partial forward integration of the breweries through contracts with an independent saloonkeeper that created certain contractual obligations on both sides. ${ }^{9}$ These contracts offered a stable, and often discounted, product price for the saloonkeeper as well as (in some cases) logistical and financial support. The overhead costs for a saloon were considerable, and they included not only capital outlays for fixtures, but also often for licensing fees. In return for the support, the retailer might be obliged to take a brewer's products or to vend those products exclusively (that is, not offer competing brands).

These contractual considerations make the relevance of Oliver Williamson's work on transaction costs to the forward integration in the brewing industry clear. Contracts that stipulated that a saloonkeeper or publican sell only the supplying brewery's beer was a vertical restraint that kept retailers from pursuing what Williamson calls "subgoals." 10 These might include appealing to a broader clientele by offering more than a single brewery's products. These restrictive clauses worried brewery regulators because they seemed to raise

8. For more on the advantages and disadvantages of full forward integration in the British market, see Mutch, "Allied Breweries."

9. A second-order tie called a loan tie.

10. For a discussion of empirical work that applies Williamson's insights to vertical market restrictions, see Lafontaine and Slade, "Transaction Cost Economics," especially 598-603. 
entry barriers to an industry by precluding the use of tied houses for distribution. British brewers, for their part, argued that these tied contracts actually lowered barriers of entry to saloonkeepers, who otherwise would not have had access to credit on such good terms. ${ }^{11}$ Interestingly, tied contracts supposedly allowed for the policing of tied houses by brewers to better maintain brand image, but this concern is absent from the American records examined for this article. The Haffenreffer Records do not make a single mention of enforcing any sort of standard décor or even handling of the beer. ${ }^{12}$ That said, many of these market restrictions were present in a 1907 contract between a brewery and Boston-area saloonkeeper Lawrence Killian. Killian had to sign both a promissory note and an agreement with the Harvard Brewing Company to supply him with the capital needed to outfit his saloon, as well as a guarantee to get "the lowest price at which your [Harvard Brewing Company's] products are sold to the retail trade in Boston." ${ }^{13}$ In return, the contract stipulated that Killian buy exclusively Harvard Brewing Company beer and that he put a large company sign over his door. Although not recorded in the contract, Killian later argued in court that he had also been guaranteed a premium if he purchased more than 750 barrels of beer a year and, in addition, would not be charged any interest on his promissory note. ${ }^{14}$

Given these basic market structures, the very different strategies of British and American brewers are striking. British beer production and consumption had been, until the expansion of the railway network in the 1830s, quite local. In what is essentially an archival lament about the paucity of records, Gourvish and Wilson note that little is known about distribution because brewer-publican contracts were mostly unrecorded. It is difficult to know the extent to which these markets were monopolistic or to what extent publicans were

11. For a discussion of the late twentieth-century attempt of the British government to reduce the supposedly market-impairing effects of the tied system, see Crompton, "“Well-Intentioned Meddling." Crompton notes that the standard defense of the breweries for the system was that it allowed new entrants in the pub trade to establish their businesses.

12. Alistair Mutch has shown that "the degree of control exercised by companies over the character of public houses [from 1850 to 1950] has been exaggerated." See Mutch, "Shaping the Public House," 179-200. The complete lack of discussion of the "character" (e.g., décor, sales of food, entertainment) in the Haffenreffer files suggests that the brewers were much more interested in exclusive access to potential customers than the retail setting. Mutch further develops the thesis of lax control over character in his work on the evolution of the role of brewery area managers in "Allied Breweries."

13. Harvard Brewing Company v. Lawrence J. Killian, 222 Supreme Judicial Court for the Commonwealth of Massachusetts (March 1915), Brief for Petitioner, at 2 (Massachusetts Supreme Judicial Court, Massachusetts Reports).

14. Ibid., Brief for Respondent, at 1. 
in debt to their suppliers. One place that the tied system was clearly important was London, as the inflation of the Napoleonic period led to the expansion of the tied system. ${ }^{15}$ Brewers acquired both leases and the loan ties in order to control publicans. Railroad networks and legislation that removed restrictions on public houses led to a dramatic increase in both per capita British beer consumption and number of public houses from the 1830s onward. The expansion in the rate of consumption began to slow toward the end of the century; along with the entry of major new competitors to the market and the increasing value of loans (partially a result of the restriction of the number of licenses in 1869), competition intensified. ${ }^{16}$ Brewers were under contemporaneous pressure to upgrade their plants (e.g., with steam power, refrigeration, and modern bottling technology) as well as to give larger loans to a smaller number of potential publicans.

A change in UK corporate law in 1884 provided a solution: brewers converted their companies into limited liability corporations and capital was provided from the issuance of debentures (some capital also came from banks). ${ }^{17}$ These securities came without voting rights or preserving family power over many breweries, and were issued with fixed, not variable, rates of interest depending on profit. D. M. Knox has argued that most of the capital raised from debenture sales was used not primarily to increase capacity but to have more money to lend to licensees or to purchase retail outlets. ${ }^{18}$ The British syndicate that owned the three Boston breweries discussed in this article used some of the money that Hagerty paid for beer and in loan servicing to then repay their debenture obligations.

Another external shock that nudged breweries toward ownership of retail outlets was a change in British law: the license inhered was for the actual building of the pub, not issued to a person.

15. Richmond and Turton, on the one hand, point to the same kind of archival silences mentioned above. They highlight the fact that there was a great deal of regional variation in the tied system and that "many country breweries had secured more sizeable estates by 1880." Richmond and Turton, Brewing Industry, 10-11. Hawkins and Pass, on the other hand, suggest that the rapid expansion of the market at mid-century meant that reliance on ties was rare, and if present at all was limited to loan-ties and seaports rather than rural areas. Hawkins and Pass, Brewing Industry, 18-19.

16. For an exhaustive history of the British brewing industry, see Gourvish and Wilson, British Brewing Industry, especially chapters 2 and 3. See also Gutzke, Protecting the Pub, especially 13-26.

17. For more on the financial pressures behind the move to brewers toward both issuance of debentures and ownership of retail outlets, see Watson, "Banks and Industrial Finance." Interestingly, Watson also describes that brewers threatened to move their businesses from one bank to another in order to secure larger loans with less collateral-similar to the micro-situation in Boston.

18. Knox, "Development of the Tied House System," 74. 
[The situation] gave premises holding such licenses a special value over and above that of the premises themselves, and the acquisition of premises having such 'monopoly value' (as it came to be called) required greater capital than was possessed by the class of people wishing to enter the retail trade. ${ }^{19}$

The result was that, whereas at the beginning of the nineteenth century British beer had largely been a semi-monopolistic, local, spot market, by the end of the century it was a competitive national market with a high degree of full forward integration. The combination of limited liability corporations and the legality of debenture issues raised the threat of new entrants into the brewing industry in the United Kingdom and forced a change in strategy toward more full forward integration.

Brewing was one of the largest manufacturing sectors in the United States in the nineteenth century and a significant source of revenue for the federal government, and, as occurred in the United Kingdom, there was large increase in total production and per capita consumption of beer from 1863 to 1865: U.S. beer production doubled from 1.7 million barrels to 3.5 million barrels. This enormous growth in productive capacity continued through the post-Civil War period until the 1890s. In that same period-fueled largely by increasing immigration from beer-drinking countries such as Ireland and Germany-the per capita consumption of beer increased from 3.4 gallons to 15 gallons per year. ${ }^{20}$ While these immigrants certainly drank beer, they also sold it: many of the saloonkeepers in my sources had either German or Irish last names: Bamberg and Bohan, Gahm and Gallagher, Hellbach and Hagerty. This incredible increase in production was driven by a number of technological innovations. First and foremost, the expansion and consolidation of the railroads allowed for brewers to ship their beer to new destinations. The spread of pasteurization and the pioneering of artificial refrigeration were key developments in the production of better beer that could keep longer. Contrary to popular belief, this was also the period in which lager began to rival ale and porter for production. ${ }^{21}$ The increase of the production of lager was driven first by central European consumers who preferred it and then by refrigeration. Lager (the German word for "warehouse") is a kind of beer that required a longer ageing period at cooler temperatures than ale or porter, which meant that ale-centric breweries had to be

19. Ibid., 67.

20. Stack, "Local and Regional Breweries," 437.

21. For the period examined, the Haffenreffer Records list beer produced at the three breweries in this article into two categories: "porter \& ale" and "lager." The latter was always greater, usually by a factor of four. Clearly, the popularity of lager was not a post-World War II trend. 
retrofitted with expensive lager "caves" (e.g., insulated basements) and later with refrigeration. ${ }^{22}$

While much of this increase in production came from large brewers that could ship their beer farther than the city limits, there were also midlevel breweries that shipped on a regional basis. In the larger Eastern seaboard cities of New York, Newark, and Philadelphia, certain breweries that rivaled the mid-Western giants Pabst and Anheuser-Busch as far as output did not ship their beer, or if they did, it was only on a very limited scale. For example, the Hells Gate Brewery, one of the largest breweries in the United States in 1890, sold most of its beer in the New York City market where it was located. Unlike the mid-Western breweries in smaller cities, the production of large-city brewers could all be absorbed by the city in which they were located. ${ }^{23}$

Martin Stack wrote that "shipping breweries" in the 1890s, the period on which this article focuses, began to lose their competitive advantage. In contrast to the trend in the three decades that followed the Civil War, between 1890 and 1920, the number of local, smaller non-shipping breweries steadily increased. Stack attributes this to these breweries piggybacking on technological changes introduced by the larger breweries; ${ }^{24}$ also important may have been the new emphasis on stock and the rise of the managerial class described by Alfred Chandler. ${ }^{25}$ Another challenge to the profits of the shipping breweries was the non-shipping breweries' ability to better control the distribution of their product. The tied system went into widespread use in the United States as early as the 1870s, perhaps in part because brewers needed capital to pay for the expensive plant improvements that their British colleagues were facing. Stack and others have investigated American pre-Prohibition beer production, and saloons have been the subject of scholarly attention, yet little research has been conducted on the connection between the two kinds of firms. ${ }^{26}$ What is still unclear about the American brewing industry of this period

22. Appel, "Building Milwaukee’s Breweries."

23. Stack gives the examples of breweries in Milwaukee (Pabst, Schlitz), St. Louis (Anheuser-Busch), and Cincinnati (Christian Moerlein), noting that these breweries either had "to limit their capacity to locally sustainable levels of production, or maximize their productive efficiency and ship their beer to other regions.” Stack, "Local and Regional Breweries," 439.

24. Ibid., 450.

25. Chandler, Visible Hand. Note that the periodization for managerial control is much different in the European context; see, for example, Iversen and Arnold, "Carlsberg."

26. For more on the U.S. brewing industry, see Stack, "Local and Regional Breweries"; Stack and Gartland, "Path Creation"; Stack and Gartland, "Repeal of Prohibition”; Appel, "Building Milwaukee’s Breweries”; Hull-Walski and Walski, “There's Trouble a-Brewin””; McGahan, "Emergence of the National Brewing 
is the character of the tied system: Why did brewers in the United States prefer to use a loan-tie rather than purchase retail outlets? More specifically, why did breweries in Boston seem to lend money at a rate far higher than these loans were repaid?

The trade press of the day, popular histories of brewing, and even some of the secondary academic literature are not helpful in resolving the paradox of brewers lending capital to debtors who were very inconsistent in meeting their obligations to repay the debt. Recent work on breweries either ignores the tied system in the United States or offers conflicting accounts of it. Despite the centrality of saloons and the tied system to the American brewing industry in the late nineteenth century, it is difficult to find mention of them in trade publications. A documentary history of the U.S. Brewers' Association made at that time does not have a single reference to the tied system and has only five references to saloons. ${ }^{27}$ An anonymous (and perhaps fictional) account penned in 1908 describes a naïve, aspiring saloonkeeper conned into taking on a lease by brewery agents. The anonymous author of the article makes it clear that his agreement with the brewery made him little more than an overworked, poorly paid employee. ${ }^{28}$ Hermann Schlüter's partisan history of the brewery workers' union, published in 1910, suggests that owners of rapidly expanding breweries actively worked to make saloonkeepers their "mere agents" 29 ; current scholars reiterate this view. Labor historian Madelon Powers, commenting on the tied system, asserts that "many urban barkeepers by the early 1900s were essentially hired hands, as subject to the directives of their brewery bosses as their wage-earning customers were to their employers." 30 Perry Duis-author of another important history of saloons-also conceived of the Boston tied system as fully forward and integrated, one with little autonomy on the part of the saloonkeeper. ${ }^{31}$ A popular history of brewing in

Oligopoly”; Mittelman, “American Brewing Industry." For more on the postWorld War II American brewing industry, see Iwasaki, Seldon, and Tremblay, "Brewing Wars of Attrition"; Gokhale and Tremblay, "Competition and Price Wars." For social histories of the saloon-the "workingman's club”-see Duis, Saloon; Powers, Faces Along the Bar; Rothbart, "Ethnic Saloon.” Victor and Carol Tremblay have written an exhaustive analysis of the post-Prohibition U.S. brewing industry, but similar research needs to be done for the nineteenth century. Tremblay and Tremblay, U.S. Brewing Industry. For a series of contemporary, global studies, see Swinnen, Economics of Beer.

27. Thomann, Documentary History.

28. McClure's Magazine, "The Experiences and Observations of a New York Saloon-Keeper as Told by Himself,” November 1908.

29. Schlüter, Brewing Industry, 252.

30. Powers, "'Poor Man's Friend,” 2.

31. Duis, Saloon, see especially 24-33. 
the Unites States echoes this view, adding that expensive municipal license fees (especially relevant to the present research) ultimately made full brewery ownership-not simply the extension of credit to independent saloonkeepers-the national norm. ${ }^{32}$ Beer historian Maureen Ogle, in her book Ambitious Brew, points to the licensing fees as a brewer's point of leverage:

The barkeeper, leashed to his brewer, had no choice but to pay the brewer's prices, not least because he was already in debt to him for the price of the license, the fixtures, and perhaps his first month's rent. The only way an otherwise honest man could make a tied saloon profitable was by steeping himself in the dishonesty of gambling or prostitution. ${ }^{33}$

Ogle also quotes the brewers' association trade journal, which, conversely, gave the impression that the saloonkeepers regularly took advantage of the vulnerable brewery agents. The trade journal recounts how the dishonest saloonkeepers played an underhanded game with brewery agents by, for example, threatening to switch away from one supplier to another. This allowed the saloonkeeper to take advantage of both agents. ${ }^{34}$ This schizophrenic view of the tied system in the United States is likely the result of a lack of available quantitative data on financial relationships of saloons and breweries.

\section{Brewing in Boston}

Because of Boston's geographic position, local breweries dominated its beer market. ${ }^{35}$ Boston was too far away from mid-Western largeand medium-sized shipping breweries to penetrate effectively. The nearest large city was New York City, but, as already mentioned, its population absorbed all of the beer that its local brewers could produce. Boston's first large brewery was opened in the late eighteenth century, and by the late nineteenth century there were more than twenty-six breweries operating in the City of Boston. This gave Boston the highest number of breweries per capita in the United States, and these breweries were mostly concentrated in the Jamaica Plain area,

32. Mittelman, Brewing Battles, 48.

33. Ogle, Ambitious Brew, 97.

34. Ibid., 94.

35. As discussed below, at least one larger saloon had an agreement with both New York's largest brewery, Hell's Gate, and with the Anheuser-Busch Company. 
which was just outside the city proper. ${ }^{36}$ In his dynamic theory of strategy, Michael Porter noted that competitive advantage cannot be examined independently of competitive scope. What Porter calls scope includes the array of buyer segments served as well as the geographic location and its degree of vertical integration. ${ }^{37}$ As made clear in the discussion below, these are relevant for understanding the conduct of the brewers and saloonkeepers in the Boston market.

Given the relative unimportance of bottled beer at this time, drinking beer required going to a hotel or saloon that held a liquor license and drinking on-site or purchasing beer in a takeaway container (called a growler). ${ }^{38}$ In 1881 the Massachusetts legislature passed a law that gave towns what was called "the local option." This meant that while there was no state-level prohibition, towns could either ban liquor or issue licenses for its sale. ${ }^{39}$ Although Boston was safely "wet," the brewers were worried about the outlying towns opting for the "dry" solution. One of the managers expressed his concern for sales in Lowell, which in 1899 had gone dry, but stated that he was confident that the decision would be reversed in the next election. This is not surprising, considering an entry from the next year: "\$305 is for contributions to the election funds of the various towns and cities outside of Boston where we do business." 40 The City of Boston, while

36. von Hoffman, Local Attachments, 57-58, 95-98; Friedrich and Bull, Register of United States Breweries, 124-126.

37. Porter, "Dynamic Theory of Strategy," 101.

38. Stack, "Local and Regional Breweries," 441. Stack specifies that "prior to 1895, 90 to 95 percent of beer was kegged, and nearly all of it was sold in saloon" (441). See also Busch, "Second Time Around," 70. Busch suggests that at the end of the nineteenth century only expensive patented medicines cost enough to merit the extra price of a bottle. This supports Stack's assertion that in nineteenth-century United States most beer was drunk from glasses filled at a saloon or from growlers at home. Hull-Walski and Walski conclude differently: they suggest that bottled lager was widespread by the end of the nineteenth century. See Hull-Walski and Walski, "There's Trouble a-Brewin.” The Haffenreffer Records almost always refer to barrels produced, and hardly ever mention bottled beer. Lawrence Killian's accounts also showed that he had purchased $\$ 10,003$ worth of keg beer in a twenty-eight month period, and only $\$ 1,912.70$ for bottled beer (also in a twenty-eight month period). "South Side of Beach St.”; Harvard Brewing Company v. Lawrence J. Killian, 222 Supreme Judicial Court for the Commonwealth of Massachusetts (March 1915), Brief for Respondent, at 34 (Massachusetts Supreme Judicial Court, Massachusetts Reports).

39. Schorow, Drinking Boston, 50.

40. Haffenreffer Files, N. E. BRG Co. Minutes-Meetings Jan. 1898-Dec. 1903, Haffenreffer Brewing Co., October 14, 1899, 5. The second reference is from page 3 of a report from the Roessle Brewery on ways to save money; it is undated but follows the minutes from February 17,1900 . This is an admittedly small attempt to influence the structure of the market, but brewers apparently later realized their error in not being more proactive in shaping legislation. For a discussion of brewer path creation just prior to the repeal of Prohibition, see Stack and Gartland, "Repeal of Prohibition." 
not outlawing the sale of alcohol, did adopt a licensing structure that became progressively more restrictive. Initially, it limited the number of licenses to one licensed retailer of alcohol per five hundred residents of the city. Licenses were expensive, initially \$150 in 1884, $\$ 500$ in 1887, and $\$ 1,000$ for the "common victualler" license used by saloons in 1890. This would be $\$ 26,606.02$ in 2015 dollars, quite the sum for a prospective saloonkeeper. ${ }^{41}$ Pressure from groups such as the Anti-Saloon League, founded in 1893, only solidified the licensing structure.

Debt and capital lending were important parts of the Boston market, as is clear from the minutes of a meeting of the members of the Committee of Management of the New England Brewing Company, held on December 16, 1900. The company was a conglomerate of the three Boston-area breweries—the Suffolk, the Boylston, and the Roessle-bought in 1890 by an English syndicate. The syndicate retained all three owners as the Committee of Management. Present at this December meeting were two of the former brewery owners, Rudolph Haffenreffer and S. C. Stanley, as well as Alvin Carl, who represented the Roessle Brewery, the largest of the three breweries. Also present was Untermyer, the previously mentioned New Yorkbased representative of the English syndicate; Untermeyer was a crucial go-between for British capital acquiring American breweries. ${ }^{42}$ The meeting began-at least as far as can be told from the minuteswith some discussion of adjusting a claim to what "was supposed to be a doubtful asset" before moving to the topic of new loans. Untermyer reminded the managers that any loans above $\$ 1,000$ first had to be discussed and have the unanimous vote of the other managers. ${ }^{43}$ Each manager then made a brief report of the loans he had recently made. One report is worth quoting in full:

A loan of $\$ 2,500$ to Jaeger \& Imbeschied, secured by a second mortgage on real estate and by the personal endorsement of both the parties, who are responsible. It is a demand loan, and is subject to the agreement that from $\$ 50$ to $\$ 100$ per month is to be paid on

41. Duis, Saloon, 27. Duis notes that this cost made Boston's licenses the most expensive in the country.

42. This acquisition of American companies, in particular breweries, was part of a much larger trend of the late nineteenth century. Samuel and Isaac Untermeyer were pioneers in arranging these purchases. For more, see O’Sullivan, "Yankee Doodle."

43. Of the 499 loans recorded in the Haffenreffer Records, the average loan was around $\$ 1,200$. From this data, and the fact that in the minutes Untermyer repeatedly reminds the managers of the need for approval of large loans-it can be assumed that loans were often for more than $\$ 1,000$, and that they were often not approved beforehand. 
account, with interest on the loan at five per cent. These customers are large consumers of beer. They are also interested in the Massachusetts Brewing Company and have since discarded the beer of that company in favor of the Roessle Brewery. On motion, duly seconded, both these loans were approved. ${ }^{44}$

This brief description of a loan to Jaeger \& Imbeschied contains all of the elements of the channel structure in Boston that I hope to illustrate in this article: the importance of brewery loans to saloonkeepers, the security that saloonkeepers offered to brewers to get these loans, and the other structural constraints on performance that impelled brewers to grant loans even when the security offered was not convincing. The ledgers suggest that saloonkeepers were neither hat-in-hand debtors who were totally beholden to the brewers, nor were they tricky shysters switching back and forth between suppliers at the drop of a hat. What is suggested here, and what emerges from the brewery records, is that saloonkeepers attempted to make a living while uncomfortably situated between their suppliers (the brewers) and their customers, between the law (liquor license regulations) and religious fervor (the temperance movement), and-most importantly-between solvency and insolvency.

When Hagerty started his saloon, he needed bars and stools and glasses, as well as a license. Killian's contract specified that he would use the $\$ 18,000$ that the Harvard Brewing Company loaned him for “license paper" $(\$ 6,500)$, the license fee itself $(\$ 1,400)$, and for fixtures and equipment $(\$ 12,000) .{ }^{45}$ In the Haffenreffer Records, loans in the earlier minutes books are often richer in description, while later entries are often quite vague. Some offer only a notation of the amount of the loan, the recipient of it, and the security, if any, offered. In 1897, Ultsch, Koch \& Co. requested a loan of $\$ 5,000$ "to enable them to build a store for their own use, and a dwelling over the same, also a stable, upon a lot they recently purchased, said loan to be secured by a first mortgage on said lot and building." 46 Before the era of zoning ordinances that separated residential and commercial property, it was common for small-business owners to live in the same building

44. Haffenreffer Records, N. E. BRG Co. Minutes-Meetings Jan. 1898-Dec. 1903, Minutes of Regular Meeting of the Committee of Management, December 16, $1900,6$.

45. Harvard Brewing Company v. Lawrence J. Killian, 222 Supreme Judicial Court for the Commonwealth of Massachusetts (March 1915), Brief for Petitioner, at 30 (Massachusetts Supreme Judicial Court, Massachusetts Reports).

46. Haffenreffer Records, N. E. BRG Co. Minutes-Meetings Jul. 1894-Feb. 1899, Minutes of Regular Meeting of the Committee of Management, March 13, $1897,147$. 
as their storefronts. As discussed below, this close association of business and home also allowed for the saloonkeeper to integrate members of his family into the business of the saloon, something that scandalized temperance proponents.

At the same meeting where they gave Ultsch, Koch \& Co. a loan, the Committee of Management also approved a loan to J. Tehan, who wanted to buy the Higgins Oyster House. The previous owner, John Judge, was heavily indebted to two of the breweries, owing the Suffolk Brewery $\$ 3,500$ and the Roessle Brewery $\$ 5,500$. The managers approved a new $\$ 3,000$ loan to Tehan, who agreed to assume Judge's debts; he secured the loan with a "first mortgage on lease, license and contents of the Higgins place." 47

The license issue in Boston was one of fundamental importance for the saloonkeepers' relationships with the breweries. On May 1, 1889 (just before the British syndicate bought the three breweries), the Boston Daily Globe reported that the new licensing cap had gone into effect and that two thousand licenses to sell alcohol in the City of Boston had not been renewed. The paper underlined the power of the temperance movement even at this early date, noting that thousands of men had been thrown out of work and "many thousands of dollars of property is wiped out of existence by this legislation." 48 One Bostonian, whose last name was Notrom, called this "an act of tyranny." 49 Considering that by 1898 no less than 250,000 of Boston's inhabitants - or 50 percent of the total population — visited a bar every day, one can imagine there would be substantial agreement. ${ }^{50}$ A grand total of 1,000 licenses to sell "intoxicating liquor" 51 were to be meted out by the Board of Police on an annual basis. The effect of this was to create a premium on liquor licenses, over and above the actual $\$ 1,000$ price.

This outcome was apparent years before the licensing limit went into effect. A representative of the city told the Boston Daily Globe that a limit on licenses would create a premium as high as $\$ 250,000$, and he was in favor of the city conducting the auction and the proceeds

47. Ibid., 147-148.

48. Boston Daily Globe, "High License in Effect," May 1, 1889, 5.

49. Boston Daily Globe, "What People Talk About," May 2, 1889, 6.

50. Schorow, Drinking Boston, 51.

51. The semantics of what actually constituted "intoxicating liquor" were important for breweries, which continued to argue that beer did not intoxicate like wine or spirits. The provision in the National Prohibition Act of 1919 (known as the Volstead Act) for the legality of beverages with an alcohol content of less than 0.5 percent by volume allowed some breweries to survive Prohibition by brewing what became called "near beer" or "small beer." However, small beer was actually a pre-1900 homebrew made with molasses or other sugar sources and usually had a low alcohol content. Downard, Dictionary, 176. 
going into the city's coffers. ${ }^{52}$ While the economic effect was not as pronounced as predicted, a premium did develop. Instead of being a windfall to the city, the premium was set by the market. Despite attempts to make premiums illegal, the licensing board "approved the recognition of the premium as an asset in bankruptcy or probate proceedings and allowed it to be sold or inherited." 53 There were, however, limitations to the license-as-asset scheme: unlike real estate property, liens were prohibited starting in 1901. The managers of the three breweries discussed this decision by the Board of Police at length, at first worrying that the decision would "diminish the security of brewers lending against saloon property." 54 However, the committee ultimately decided:

The regulation in question should not be permitted to interfere with the conservative lending of money on saloon property, as after all the security depends on that success of the business; if successful the brewers are paid, and if unsuccessful the license is worthless in any event. ${ }^{55}$

This passage makes it clear that the brewers had up to that point been using liens against the licenses rather than the property to secure their loans, and in the case of bankruptcy of a saloon, only the nominal and premium parts of a license's value were assets, not the liens against it. Even though brewers knew liens would not be recognized in court, at least one loan was secured with it after the 1901 prohibition. ${ }^{56}$

The costs of opening a saloon in Boston were thus high. Some Bostonian barkeepers decided that they could more afford the risk of being caught without a license than the risk of borrowing the necessary funds for one. ${ }^{57}$ Other than perhaps increasing the number of illegal saloons, the results of these growing start-up costs were twofold. First, in an attempt to gather the capital necessary while maintaining a degree of independence from the breweries, more saloons in Boston were partnerships as opposed to individual proprietorships.

52. Boston Daily Globe, "Auction Plan: Gen Martin Favors It in Granting Licenses. Would Have the 91 New Ones Go to Highest Bidders," August 20, 1895, 6. 53. Duis, Saloon, 32.

54. Haffenreffer Records, N. E. BRG Co. Minutes-Meetings Jan. 1898-Dec. 1903, February 9, 1901, 4.

55. Ibid., 4-5.

56. Ibid., June 16, 1903, 1. The $\$ 2,400$ loan to the Stapleton brothers is followed by "Secured by mtge. on personal property, lien on license" (ibid.).

57. Boston Daily Globe, "Where Boston Women Drink: Many Strange and Surprising Experiences of a Globe Woman in the Numerous Places in This Town Where Women Tipple," February 26, 1894, 5. 
Of the ninety-six different recipients of loans from the breweries in the period recorded in the Minutes books, twenty-seven were explicitly partnerships. ${ }^{58}$ I conjecture that this number means that most partnerships had sufficient capital to not need loans from the breweries; nevertheless, the presence of a significant number of partnerships also shows that even pooling resources was sometimes not enough to overcome the increased need for start-up capital.

Second, prospective saloonkeepers turned to the breweries for loans. Not surprisingly, Untermyer, in addition to reiterating that the managers needed to discuss all loans above $\$ 1,000$, also motioned that "the character of the security offered for the loans" be presented before loans were granted. ${ }^{59}$ Prospective saloonkeepers offered a wide variety of collateral with their loan requests. At a special meeting with the managers and their legal counsel, the Harrington brothers of Charlestown requested the relatively small amount of $\$ 500$, with "said loan to be secured by deposit of whiskey certificates." 60 Shares such as these, as well as stocks and bonds, were unusual as securities for loans, although there is one other instance in which "a security of $\$ 5,000$ of quarry stock, which is payable in dividends" was given for a loan of $\$ 2,000.61$ Another relatively uncommon security was a life insurance policy. In one of the nine ledger entries that contain the phrase, William Hellbach received $\$ 2,000$, having signed a chattel mortgage "and assignment of life insurance policy for $\$ 5,000$, also lease." 62 Chattel mortgages were mentioned in 33 of the 499 loans recorded, and saloon historian Perry Duis makes explicit that they often contained a clause that made the "tied" relationship explicit, prohibiting the saloonkeeper from selling anyone else's beer. ${ }^{63}$

The vast majority of the notations concerning the collateral offered to the brewers for loans contain some variation on a personal promissory note (e.g., "note," “demand note," "time note”) either alone or with another security such as a mortgage or with an endorsement.

58. Because the majority of business names are listed as, for example, "Murphy \& Co.," it is difficult to say with certainty how many were actually partnerships, despite the name. I have included companies whose names included "\& Son(s)" or "\& Brother(s)" in this count.

59. Haffenreffer Records, N. E. BRG Co. Minutes-Meetings Jan. 1898-Dec. 1903, June 10, 1899, 5.

60. Haffenreffer Records, N. E. BRG Co. Minutes-Meetings Jul. 1894-Feb. 1899, March 30, 1897, 152. These certificates were shares issued by distilleries on multi-gallon cases and represented a small futures market within the alcohol industry. Behr, Prohibition.

61. Ibid., November 12, 1898, 237.

62. Haffenreffer Records, N. E. BRG Co. Minutes-Meetings Jan. 1898-Dec. 1903, June 16, 1900, 1.

63. Duis, Saloon, 26. 
Of the 499 loans, 138 contain an annotation with "note" in it. Of Hagerty's six loans, only one had an annotation of collateral offered at all: in May 1898, he received \$800 “on note.” Killian had also signed a similar note with the Harvard Brewing Company. On October 7, 1907, he agreed to pay “on demand” $\$ 2,500$ at any bank in Boston, with 6 percent interest until paid. ${ }^{64}$ The Massachusetts Supreme Court had ruled in 1894 that conveying notes when either "insolvent or in contemplation of insolvency" was a fraud, and brewers were, of course, aware that a note was only as good as the assets and future wages of the person in question. ${ }^{65}$ A note in the January 1899 minutes reflects this: "Accounts of Simonds and Crafts for \$150 and $\$ 1,000.00$ respectively, charged to Bad Debts, represent judgements [sic] against those parties, which will permit recovery within twenty years provided either of them should become possessed of any property."66

While most of the loan notations are brief, the meeting minutes occasionally (especially in the earlier part of the period examined) provide more information about the criteria used by the managers to vet the applicants. Along with the actual securities, the relationship with the recipient of the loan is sometimes cited. A Mr. Galivan, who had offered the quarry stock as collateral, was judged "an old and valuable customer and perfectly responsible"; at the same meeting, the managers made a loan to Carl Schleicher of $\$ 2,000$. Schleicher had to sign a demand note, even though the minutes noted "both he and his wife are responsible." 67 Saloonkeepers who already enjoyed relationships with the brewers and who could put up at least part of the money for their new businesses were also likely to receive loans. The December 1900 meeting was seemingly only about potential "new trade"; a request from Edward Finnin, a former employee of the Roessle Brewery, is described as "being secured by chattel mortgage." Finnin proposed to use the $\$ 3,500$ for part of the price of saloon property, paying the $\$ 2,900$ balance himself. "It is considered a safe and lucrative investment," noted the minutes. "On motion, duly seconded, the loan was approved." 68

Another variable that seemed to make loans more likely to be approved was one that might lead to a second customer. Along with

64. Harvard Brewing Company v. Lawrence J. Killian, 222 Supreme Judicial Court for the Commonwealth of Massachusetts (March 1915), Brief for Respondent, at 26 (Massachusetts Supreme Judicial Court, Massachusetts Reports).

65. Massachusetts Supreme Judicial Court, Massachusetts Reports, 645.

66. Haffenreffer Records, N. E. BRG Co. Minutes-Meetings Jul. 1894-Feb. 1899, January 14, 1899, 249.

67. Ibid., November 12, 1898, 238.

68. Haffenreffer Records, N. E. BRG Co. Minutes-Meetings Jan. 1898-Dec. 1903, December 16, 1900, 5 . 
the assertion that P. C. Crowley was "perfectly responsible," Alvin Carl (the manager of the Roessle Brewery) pointed out that the loan would secure "his trade in addition to the trade of a son-in-law of Mr. Crowley's. Upon this statement the loan to Mr. Crowley is unanimously approved." 69 The best of all worlds for the brewers, though, was an existing customer who made large purchases. To return to the example of the Jaeger \& Imbeschied loan that this section began with: "These customers are large consumers of beer. They are also interested in the Massachusetts Brewing Company and have since discarded the beer of that company in favor of the Roessle Brewery."70 With only one thousand possible outlets for their beer in the Boston market, the brewers were constantly worried about expanding their trade visà-vis other breweries. That is not to say that all applications were approved: the "Application of Mr. O'Connor for \$3,500 [...] was declined for the reason that he could offer no security and that he was not regarded as a desirable customer."71

\section{From Entrepreneur to Employee: The Exceptional Case of P. J. Hagerty}

Perry Duis, in his account of saloons in the urban history of Boston and Chicago (in a chapter entitled "From Entrepreneur to Employee"), highlights the visible changes that occurred as the tied system spread through U.S. cities. Duis cites the change in signage, asserting that while in the past the name of the saloon owner had been prominent, "after the brewer took over, its brand and its symbol were the largest things on the door. [...] The entrepreneur had become the employee."72 The photograph at the beginning of this article seems to prove Duis's assertion, as does the clause in Killian's contract with the Harvard Brewing Company to place the sign "Harvard Beer and Ales" above his door. ${ }^{73}$ In figure 1, the larger of the two Roessle signs is more visibly luminescent compared to the two signs below it;

69. Ibid., July 8, 1899, 5 .

70. Ibid., December 16, 1900, 5-6.

71. Haffenreffer Records, N. E. BRG Co. Minutes-Meetings Jul. 1894-Feb. 1899, May 8, 1897, 158.

72. Duis, Saloon, 43.

73. Historic New England, Photograph Albums Collection, Boston Streets and Real Estate, Album \#207, South Side of Beach St. near Corner of Atlantic Ave., Boston, Mass., March 15, 1901, Cyanotype, March 15, 1901. Harvard Brewing Company v. Lawrence J. Killian, 222 Supreme Judicial Court for the Commonwealth of Massachusetts (March 1915), Brief for Respondent, at 28 (Massachusetts Supreme Judicial Court, Massachusetts Reports). 
its whiteness suggests newness, whereas the other signs seem to have an accretion of soot on them. Does this seeming visual confirmation of Duis's thesis-that the tied system as it was practiced in Boston represented the final, complete, and economic subjugation of the saloonkeeper by the forward integrating breweries-find corroboration in the archives? As Duis himself points out in the subsequent chapter, "often illiterate and lacking business experience, these small merchants [saloonkeepers] kept very few records."74 Because of the relationship that the tied system created, though, the breweries' records can perhaps function as a stand-in for the records that saloonkeepers may never even have kept.

Hagerty's saloon provides a test case for the oppressiveness of the tied system. Hagerty's name appears in twenty-nine separate entries in the Haffenreffer Records. For the first six repayment entries, Hagerty is listed together with someone who may have been his partner-perhaps one of the two men standing in the doorway of the saloon in figure 1. The entry name "O'Connell and Co. and P. J. Hagerty" make it clear that Hagerty was a later addition to the partnership, perhaps to provide an infusion of capital for the saloon. Between October 1897 and February 1898, the pair made monthly payments of between $\$ 100$ and $\$ 150$, although in March 1898, Hagerty was listed by himself for the first time. It is impossible to know how much money the partners owed the Roessle Brewery prior to the beginning of the Haffenreffer Records, but Hagerty received six loans between October 1897 and September 1900 for a total of $\$ 3,962 .{ }^{75}$ Between March 1898 and August 1900, Hagerty made mostly monthly repayments of, on average, just under \$200. The final payment was quite a bit higher, at $\$ 912$. Thereafter, Hagerty's name vanishes from the Haffenreffer Records.

Hagerty's known life before and after his brief appearance in the Haffenreffer Records is fragmentary at best. The 1900 U.S. census listed him as living at 61 Rockwell Street in Boston's Ward 24

74. Duis, Saloon, 46. Though Duis draws on a wide array of sources-court cases, trade journals, newspaper reports, etc.- to substantiate his claims, he does not cite any brewery or saloon records. This is likely due to their inexistence or inaccessibility. I believe the Haffenreffer Records, until only recently in family hands, are the only records to have survived. I attempted, altogether unsuccessfully, to locate any saloon's records. The best possibility was the Jacob Wirth Saloon in central Boston, in business since the late 1800s, but it was sold by the family decades ago, and any records were apparently lost or destroyed.

75. Only one loan, from May 1898, has any security listed as “on note.” It may appear odd that while O'Connell and Co. figures in the repayments until February 1898, Hagerty received a loan by himself five months earlier, in October 1897. It is possible that this first loan (for $\$ 1,000$ ) was to buy out O'Connell and Co. and still have money for running expenses. 
(Dorchester), together with his mother, Mary Hagerty (born in Ireland, birthdate "unknown"), and his two older sisters, Annie and Ellen. P. J. (full name Patrick James) was twenty-nine years old and his occupation was listed as "liquor dealer."76 The 1910 Boston census does not list any of the four family members, but by 1920 Patrick and his two sisters are back on Rockwell Street, although now several doors down. Patrick was listed as fifty-two years old and as an "upholsterer."77 The years between 1900 (when he is listed in the census and makes his final payment to the Roessle Brewery) and 1920 are difficult to reconstruct. Hagerty's total for loans received from Roessle was $\$ 3,912$, and his repayments totaled $\$ 3,962$. It is impossible to say with certaintygiven the fact that the loan history prior to 1897 is not available-but it appears that with his final, unusually large payment, Hagerty paid off his loan account with the Roessle Brewery.

Despite the brewery trade journal's statement cited above, the data examined here suggests that changing brewery suppliers was an uncommon occurrence. Assuming that Hagerty had, indeed, paid off his loans, it would seem that he continued buying beer from the Roessle Brewery. Hagerty made his final loan payment in September 1900, and in March 1901 he still has the signs for the Roessle Brewery's premium lager (clearly visible in figure 1). After the final payment, the terms of the agreement may have changed; perhaps Hagerty kept the signs in return for continuing to serve only Roessle products, or perhaps he negotiated a better price for the beer. It is not possible to know whether this relationship continued for long. In 1905 Hagerty applied to the city council for permission to put up "illuminated signs at 151 Beach St., Wd. 7."78 These signs may have read "P. J. Hagerty" in large, well-lit letters, or perhaps they read "Roessle Premium Lager," but at some point between 1905 and 1920, as made clear from the census records, Hagerty left saloon work for wages as an upholsterer. The question remains of what meaning to attribute to these few dozen entries in ledgers and a single photograph with no subjects identified. ${ }^{79}$ It seems clear that the debt peonage that Duis attributes to the relationship between the brewer and the saloonkeeper, at least in the case of Boston, may be exaggerated. At the same time, perhaps Hagerty was the exception to the rule. Only saloonkeepers who were able to repay their debts as quickly as Hagerty could escape the pseudo-category of a precarious brewery employee.

76. Bureau of the Census, Twelfth Census of the United States, Sheet 13.

77. Ibid., Fourteenth Census of the United States, Sheet 2a.

78. City Council of Boston, Reports, 154.

79. For a discussion of the dangers of excavating old photographs for meaning, see Bousé, "Restoring the Photographed Past." 
To better understand this, trends in loan making and repayment are needed: this will not only allow Hagerty to be classified as a statistical outlier, but also to see how both saloonkeepers and brewery owners used outstanding loans as leverage.

The three breweries in this sample seemed reluctant to miss the opportunity to loan money to a prospective saloonkeeper. While there was, of course, always the risk that a saloonkeeper would default, there was also the danger that refusing loans to potential saloonkeepers would send them straight into the arms of the competition. Using Porter's terms, the bargaining powers of the buyers and the competition among the breweries in an artificially small market for retail outlets influenced the conduct of the participants. The risk of default could be lessened through proper vetting, but the danger of losing clients was real, and evidently concerned the brewery managers. In July 1898, Rudolph Haffenreffer made an accounting of the customers he had lost. He reported that several saloonkeeper clients had gone elsewhere because of his "unwillingness to make large and insecure loans," which they ultimately procured from his competitors. The minutes then record Untermyer recommending to both the committee and to the London Board that Haffenreffer be encouraged "to make conservative loans for retrieving his trade." 80 Far from being subservient to a monopsonic lender, saloonkeepers were able to use the fact of limited Boston retail outlets to secure large loans from brewers.

This passage in the minutes is revealing in that it shows how Boston's industrial product channel put the managers between the proverbial rock and a hard place. Haffenreffer's comments were not part of a reporting of customers made and lost, but rather a defensive response to Untermyer's request for "an explanation of the large and continuous falling off in output." 81 As I show below, the managers were under constant pressure from both Untermyer and the London secretary of the syndicate to remit money that could then be distributed to holders of the syndicate's stock and debentures. Katherine Watson has shown that the second wave of British brewery acquisitions of public houses occurred in the late 1890s. The syndicate purchased the three Boston breweries in 1890, just as the first wave of UK public house purchases was beginning. It seems reasonable to conjecture that this American capital was being remitted to Britain not only for the syndicate to provide dividends, but also to be used as collateral for mortgage debt on public houses there. Regardless of what these remittances were for, it is clear from the minutes that

80. Haffenreffer Records, N. E. BRG Co. Minutes-Meetings Jul. 1894-Feb. 1899, July 9, 1898, 219.

81. Ibid. 
they constrained the managers' ability to make the loans that would ensure future cash flow to pay remittances. During the February 1900 managers' meeting, after a request from Untermyer to remit the rest of the $\$ 70,000$ needed for payments to shareholders, the managers complained that further remittances before the May 1 licensing period would make them "very much cramped in the making of advantageous loans [and] in that respect are not able to compete on equal terms." 82 At the June meeting of the same year, two of the three managers reported that they had applied for and received large personal loans from a Boston bank. One specified that he had done this "for the purpose of advancing to his customers on May 1st to enable them to pay their licenses and also for several loans which he was compelled to make in order to secure new business." ${ }^{83}$ This back-and-forth between Untermyer and the managers about the remitting of profits, as opposed to using them to fund new loans, repeats itself in four of the ten years for which there are records. Hatten, Schendel, and Cooper, although discussing the U.S. brewing industry in the second half of the twentieth century, note that one of the key strategic variables for competition within an industry is financial policy. ${ }^{84}$ The intra-industry group of three brewers were clearly in agreement that a greater use of capital for long-term debt would make them more competitive in the Boston market, but their British owners were driven by their own debt requirements, that is, the need to pay debenture interest.

This explains a startling observation that emerges from a close analysis of the data. Despite the admonitions about vetting all loans with a detailing of the collateral offered and making "conservative" loans, 217 of the 499 loans made had no notation at all about the security, not even promissory notes. Given that the average loan in the sample was $\$ 1,200$ ( $\$ 34,463$ in 2015 dollars), the overwhelming number of loans made could be regarded as risky, according to Untermyer's threshold of $\$ 1,000 . .^{85}$ It is in this context-brewery managers' need to remit money to London with the simultaneous need to use loans to secure what they referred to as "trade" (i.e., saloons as new retail distribution)—it is possible to make sense of the most puzzling aspect of the records: the saloonkeepers systematic failure to pay back the loans they had received.

82. Haffenreffer Records, N. E. BRG Co. Minutes-Meetings Jan. 1898-Dec. 1903, February 17, 1900, 5.

83. Ibid., June 16, 1900, 5.

84. Hatten, Schendel, and Cooper, "Strategic Model,” 592. The authors' discussion of the differential use of debt (i.e., their ratios of debt to invested capital) among various strategic groups of firms seems relevant to the present discussion.

85. The Inflation Calculator, http://www.westegg.com/inflation/infl.cgi. This calculation used $\$ 1,200$ in the year 1900 as a baseline for calculation. 
While some of the notations in the minutes or the entries in the data give payment schedules, it is difficult to find a saloonkeeper that paid according to the agreed-upon schedule or even on a regular basis. This is why Hagerty is the statistical outlier in the data set. An example from the June 1899 meeting is reflective of the overall trend that emerges from the loan data. In the same meeting in which Untermyer exhorts the managers to carefully review all requests for loans above $\$ 1,000$, as well as the securities offered, Heffenreffer announces that "it will be necessary for him to loan a customer named McNamara $\$ 7,000$." Haffenreffer makes it clear that the reason is that he considers it "necessary to retain his [McNamara's] trade." McNamara is good for the money, Haffenreffer assures the rest of the committee; he has no doubt that McNamara will pay the $\$ 7,000$ back within a year. After Haffenreffer states that he will make the loan from his own funds if the company does not advance the money, the committee approves the loan. ${ }^{86}$ McNamara's repayments are listed in Table 2, which shows that they were both occasional and insufficient to repay the loan.

Other loan recipients, like Hagerty, made good on their loans (Finnin, the former brewery worker, paid back $\$ 3,500$ within two years), but most were delinquent. In the same meeting in which the managers approved Finnin's loan, a loan of $\$ 2,000$ was made to J. J. Donovan “on Donovan's demand note, with responsible endorsers." Carl justified the loan by saying: "Donovan has just opened a new place, costing $\$ 5,700$, he and his partners having paid cash for the entire place." The difficulty of resisting a loan to a new saloonkeeper-and one with multiple partners and enough cash to buy a saloon outright-is obvious. Donovan made exactly one payment of $\$ 100$ on this loan, twelve months after it was approved, and thereafter disappeared from the brewery minutes. ${ }^{87}$ Several of the largest loans are the most

Table 2 Loan repayments of John McNamara

\begin{tabular}{lc}
\hline Date & Loan Repayment \\
\hline October 1899 & $\$ 50$ \\
July 1900 & $\$ 200$ \\
August 1900 & $\$ 500$ \\
September 1900 & $\$ 250$ \\
October 1900 & $\$ 200$ \\
November 1900 & $\$ 550$ \\
December 1900 & $\$ 100$ \\
Total & $\$ \mathbf{1 , 8 5 0}$ \\
\hline
\end{tabular}

Note: John McNamara's irregular and small payments were not sufficient to repay the $\$ 7,000$ borrowed from the New England Brewing Company.

86. Haffenreffer Records, N. E. BRG Co. Minutes-Meetings Jan. 1898-Dec. 1903, June 10, 1899, 6-7.

87. Ibid., January 21, 1902, 1. 
compelling examples. In July 1898, Enrico Tassinari was given a loan for $\$ 13,000$, the largest single loan of the entire data set. During the next twenty-eight months, Tassinari made only seven repayments, totaling \$1,750. From November 1900 through August 1903, he made no payments at all. His repayments-which can be referred to as "sporadic" only with a generous spirit-was rewarded with a new loan for another $\$ 6,000$ in July $1903 .^{88}$ Tassinari had evidently taken on his son as a partner, as thereafter his repayments are noted under the name "Tassinari and Son." From August through November 1903, the Tassinaris repaid $\$ 1,000$ per month, but unfortunately the data set ends with the close of that year. We can only hope that the younger Tassinari's apparent good influence continued.

While Tassinari's first loan is the most egregious example of not repaying what was owed, there are scores of other loan recipients who appeared delinquent in their payments. Given the short time period covered by these data-rich entries, ${ }^{89}$ the number of saloonkeepers that received new (and often large) loans, despite only occasional repayments, is quite large. It seems that debt-or, more specifically, a very fluid and competitive market for new loans from competing brewers-was a tool more often used by saloonkeepers than brewers. Despite frequent discussion of loans in the many recorded regular meetings of the Committee of Management, 114 in all for this article, in only three instances was there even a mention of bad debts, and one of these is noted in the context of possible future collection. That said, the brewers used debt as a lever of power-that is, a strike (which is discussed at length below) -in a moment of necessity.

Why were the saloonkeepers so lax about repayment, and why did the brewers not use the leverage they had more frequently? Ogle cites an exasperated brewery collector, who wrote to the company's owner:

You would not think of giving this amount of money to any reputable man without security. Why would you give it to strangers who in asking it have to admit that they have not the necessary funds to carry on the business ... [T] his kind of loan system is the weakest spot in your whole business and subjects you to more losses, and to more expense and unsatisfactory litigation, than all your other business put together. ${ }^{90}$

88. Ibid., August 18, 1903, 1. Unlike the first loan, which had no security listed, this second one was secured by an "Endorsement."

89. The short chronological span necessarily leaves out the possibility of large loans that were given just before they begin to be recorded in 1897, or large repayments made in 1904. Given the large number of entries, it seems safe to assume that the trends are statistically significant.

90. Cited in Ogle, Ambitious Brew, 95. 
Unless greater financial rationality is attributed to the collector than to the brewery owner, these unsecured loans require explanation. The qualitative data available in the minutes show the importance the managers gave to maintaining their existing saloon clients and to gaining new ones; this data is corroborated by the quantitative data available on the balance sheets prepared each year by Deloitte, Deer, Griffiths \& Co. ${ }^{91}$ (see table 3).

The balance sheets record the income and expenses for all three breweries and provide expenses both in gross terms and in the cost per barrel. It is clear from even a cursory look at brewery finances that bad loans were treated almost like an operating cost; indeed, several times the entry for "Bad Debts" appears not on its own page but with other operating expenses. Bad debts were a relatively minor expense: over the nine years recorded, the average cost was only $\$ .11$ per barrel. This was more than horsefeed and advertising, but it was ultimately a fraction of the major expenses of primary materials (the hops, malt, and water) that, on average, cost $\$ 1.52$ per barrel. For comparison, the collectors' salaries and "expenses" (e.g., free drinks for saloongoers when the collectors made their rounds) were $\$ 1.82$ per barrel in 1901. The total cost per barrel of federal revenue stamps (i.e., the federal taxes on beer) was $\$ 2.03$ per barrel. This is not to say that the weight of the loans on the balance sheet was light. Despite revenue of

Table 3 Data for available years for the amalgamated revenue and expenses for the three Boston breweries

\begin{tabular}{llcccccc}
\hline Year & Revenue & $\begin{array}{c}\text { Bad } \\
\text { Debts }\end{array}$ & $\begin{array}{c}\text { Bad } \\
\text { Debts as } \\
\% \text { of } \\
\text { Revenue }\end{array}$ & $\begin{array}{c}\text { Bad } \\
\text { Debts } \\
\text { /bbl }\end{array}$ & $\begin{array}{c}\text { Materials } \\
\text { /bbl }\end{array}$ & $\begin{array}{c}\text { Advertising } \\
\text { /bbl }\end{array}$ & $\begin{array}{c}\text { Horsefeed } \\
\text { /bbl }\end{array}$ \\
\hline 1891 & $\$ 1,289,918$ & $\$ 6,791$ & $0.5 \%$ & $\$ 0.03$ & $\$ 2.19$ & $\$ 0.01$ & $\$ 0.07$ \\
1892 & $\$ 1,189,739$ & $\$ 17,845$ & $1.5 \%$ & $\$ 0.09$ & $\$ 1.69$ & $\$ 0.03$ & $\$ 0.07$ \\
1895 & $\$ 1,155,721$ & $\$ 2,445$ & $0.2 \%$ & $\$ 0.01$ & $\$ 1.48$ & $\$ 0.03$ & $\$ 0.05$ \\
1899 & $\$ 1,031,829$ & $\$ 20,193$ & $1.9 \%$ & $\$ 0.13$ & $\$ 1.32$ & $\$ 0.08$ & $\$ 0.06$ \\
1900 & $\$ 1,041,653$ & $\$ 7,349$ & $0.7 \%$ & $\$ 0.05$ & $\$ 1.29$ & $\$ 0.06$ & $\$ 0.06$ \\
1901 & $\$ 706,021$ & $\$ 20,015$ & $2.8 \%$ & $\$ 0.14$ & $\$ 1.36$ & $\$ 0.04$ & $\$ 0.07$ \\
1902 & $\$ 639,033$ & $\$ 32,502$ & $5.0 \%$ & $\$ 0.23$ & $\$ 1.45$ & $\$ 0.03$ & $\$ 0.09$ \\
1903 & $\$ 800,868$ & $\$ 16,246$ & $2.0 \%$ & $\$ 0.10$ & $\$ 1.46$ & $\$ 0.04$ & $\$ 0.08$ \\
1904 & $\$ 801,498$ & $\$ 32,604$ & $4.0 \%$ & $\$ 0.20$ & $\$ 1.48$ & $\$ 0.04$ & $\$ 0.08$ \\
Averages & $\$ 961,809$ & $\$ 17,332$ & $2.1 \%$ & $\$ 0.11$ & $\$ 1.52$ & $\$ 0.04$ & $\$ 0.07$ \\
\hline
\end{tabular}

Note: Bad debts were a small portion of the cost per barrel (bbl) of beer.

91. Haffenreffer Records, N. E. BRG Co. Amalgamated Profit \& Loss Accounts, all years. The collection of balance sheets is incomplete, although some cases contain both the amalgamated numbers as well as more detailed balance sheets for the individual breweries. 
just more than $\$ 700,000$ dollars in 1901 , the combined outstanding loan accounts of the three breweries (present in the minutes books but absent from the balance sheets) totaled $\$ 319,452.16 .^{92}$ The year in which bad debts were the highest percentage of the total cost of a barrel of beer was 1902, undoubtedly because of the strike (discussed next). In that year, bad debts amounted to $\$ 32,502.31$ across the three breweries, compared to total gross revenue of $\$ 639,033.13$. Even at this low point of the years surveyed, the debts accounted for only 9 percent of the total expenses, and only $\$ 0.23$ cost on each barrel of beer. ${ }^{93}$

\section{The Strike and Conclusions}

In the minutes for March 1902, there is brief reference to "the demand of the labor unions for decreased hours and increased wages," although there seems to have been little discussion other than a calculation of what acceding to these demands would cost the three breweries. ${ }^{94}$ By the next meeting of the managers, on April 15, 1902, the strike was in its second week. All three brewer-managers reported that they were still brewing in a "more or less satisfactory manner," and that while many workers were still out, some had come back. The minutes closed with the observation that the Retail Liquor Dealers Association of Boston had voted to use "Boston-brewed" (i.e., scab) beer, and that this would likely lead to a speedy conclusion to the strike.

Despite their predictions, the strike wore on. Some of the city's saloonkeepers decided to support the strike and refused to take beer brewed by the scabs. The brewery owners turned the screws. In the minutes of their September meeting, the brewers stated: "It was found necessary to demand the payment of large loans made to customers, who by reason of the strike, ceased buying." 95 It is, unfortunately, impossible from the records at hand to determine what specific effect that threatened call had, but by the end of that month the

92. Haffenreffer Records, N. E. BRG Co. Minutes-Meetings Jan. 1898-Dec. 1903, January 21, 1902, 1-3. The Roessle Brewery reached its highest point of indebtedness in the minutes of the regular meeting on May 17, 1901, with $\$ 151,604.71$ in loans outstanding. Ibid., May 17, 1901, 2.

93. Haffenreffer Records, New England Brewing Company Amalgamated Profit \& Loss Accounts December 31, 1902.

94. Haffenreffer Records, N. E. BRG Co. Minutes-Meetings Jan. 1898-Dec. 1903, March 12, 1902, 4-5.

95. Ibid., Minutes of Regular Meeting of the Committee of Management, September 12, 1902, 5. 
strike was over. It seems, given the complaints from the London secretary about the large decline in the number of barrels sold, that the strike had some impact on consumption, but that the saloonkeepers-the crucial link in distribution-seemed to have mostly sided with the brewers. ${ }^{96}$ Although there was undoubtedly some support for the strikers by saloonkeepers, as they initially refused to sell "scab" beer, those with outstanding loans to the brewers could not afford working-class solidarity.

A channel organization diagram (see figure 2), edited to reflect the evidence presented in this article, allows certain conclusions to be drawn about the ultimate absence of complete forward integration

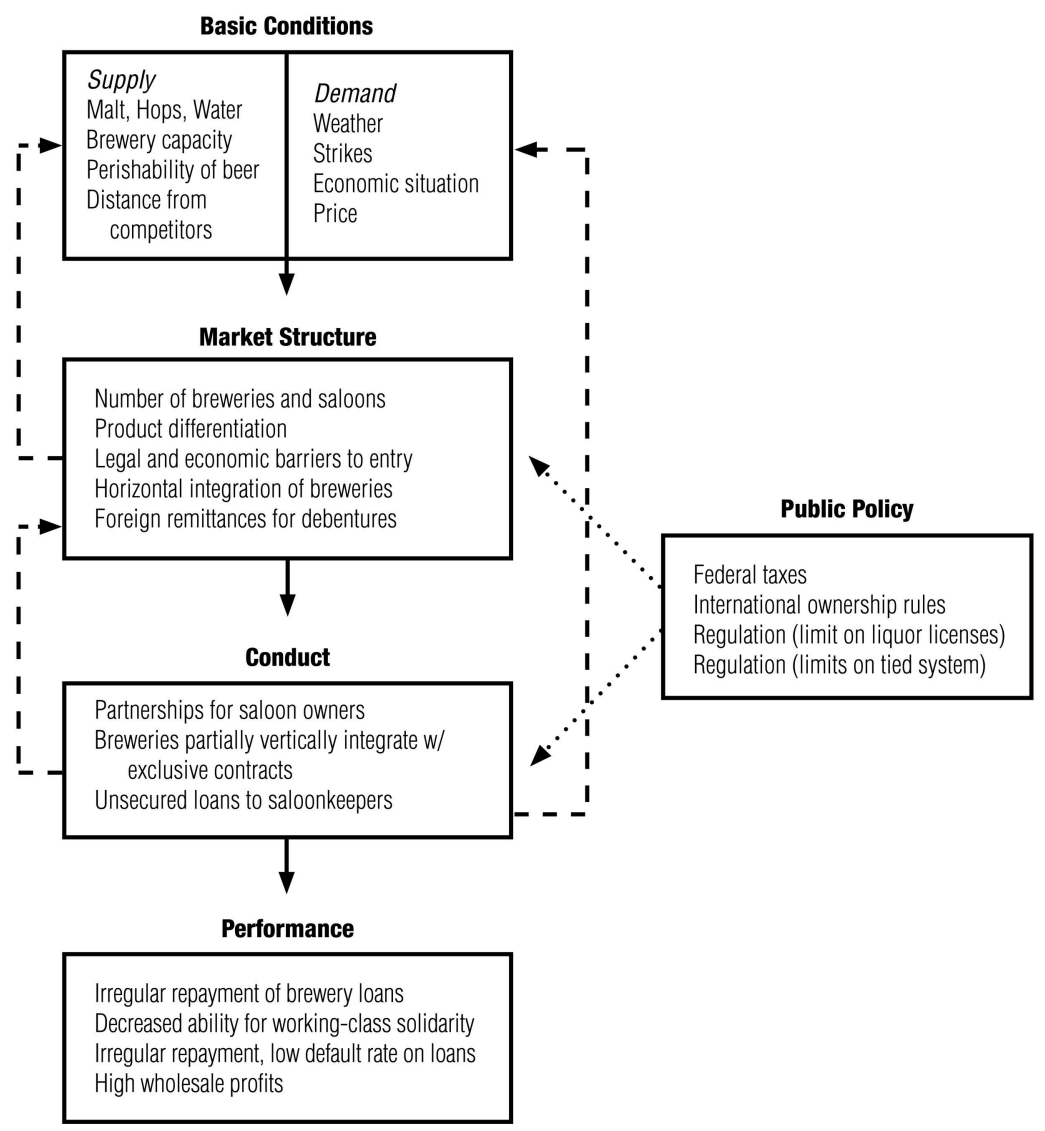

Figure 2 A brewery-specific channel structure showing legal and financial feedback loops. (Based on Scherer and Ross, 1990.)

96. Ibid., June 10, 1902, 4-5. Compared to May 1901, the Roessle Brewery lost 22.2 percent, the Haffenreffer Brewery 35.4 percent, and the Suffolk Brewery 20.4 percent. 
in Boston's early nineteenth-century brewing industry. Despite the fact that a more complete set of documents-for example, at least one saloonkeeper's account book-would offer a much more definitive set of data on which to draw assertions, the Haffenreffer Records do allow for some conclusions. In contrast to previous portrayals of the tied system, which located all the leverage with either the brewer (the despot with the promissory note) or the saloonkeeper (the unreliable operator free to switch suppliers at any time), the documents surveyed here suggest that the relationship was a more complicated one.

While the market structure in Boston-the need for licenses to sell beer-made the brewer the holder of a legally enforceable financial obligation, the saloonkeeper enjoyed a privileged position. Given Boston's distance from other major centers of beer production, as well as New York City's ability to consume all of the beer it produced, beer sold in Boston was largely produced by local brewers, another unique characteristic of the brewing market structure in the Hub. Boston was the eighth-largest revenue district in the country in 1907, according to the secretary of the brewery trade association ${ }^{97}$; the combination of Boston's size and isolation created a capital lending market that gave the saloonkeeper a certain advantage. The local brewers' Board of Trade made attempts to create a cartel to artificially inflate prices and reduce competition between brewers, but its failure is clear in the Haffenreffer minutes. ${ }^{98}$

Because of the small size of the bottled beer trade, the breweries were in competition not so much for consumers as for distributors. ${ }^{99}$ The tight regulation of the number of licenses in the City of Boston and the existence of the local option in the outlying towns and small nearby cities made saloonkeepers a critical player in the beer market. As Wade, Swaminathan, and Saxon have shown in their investigation of restricting alcohol markets, "the normative and resource effects of government regulations often generate externalities, that is, the private costs and benefits for the decision makers are not the full costs

97. Fox, "Prosperity of the Brewing Industry," 50.

98. The references to the Board of Trade and its ineffectual attempts to restrain competition between the brewers are numerous in the Haffenreffer Records. See, for example, Haffenreffer Records, N. E. BRG Co. Minutes-Meetings Jul. 1889-Feb. 1899, the undated Roessle Brewery cited above (which follows the minutes from February 17, 1900, in Haffenreffer Records, N. E. BRG Co. Minutes-Meetings Jan. 1898-Dec. 1903), and Haffenreffer Records, N. E. BRG Co. Minutes-Meetings Jan. 1898-Dec. 1903, Minutes from February 9, 1901; March 15, 1901; and February 17, 1903.

99. Stack and Gartland note that national brewers' successful lobbying for the legalization of other retail outlets for beer, and the rise in the use of bottled beer (vis-á-vis keg beer) led to the undermining of local breweries, which could no longer control its markets. Stack and Gartland, "Repeal of Prohibition." 
and benefits for the decision." 100 In other words, governmental distortions of the market conditions created asymmetrical advantages and disadvantages, something clear in these records. Despite their indebtedness to the breweries, saloonkeepers were able to use these market conditions to extract advantageous conditions on loans. The loans thus represented an excellent investment for the brewer; even though repayment on the loans was sporadic at best, the loan guaranteed greater access to the consumer and offered a continuous source of revenue. As shown, the loan was still a guarantee that the saloonkeeper would use only that brewery's beer, and it was leverage that was used when required, as in the strike.

At the same time, the loan represented a sunk cost for the brewery, in return for which they were able to demand both "brand loyalty" and a steady stream of current income: the payment for the beer itself. Lawrence Killian's loan agreement with the Harvard Brewing Company specified quarterly loan repayments, but there is no evidence that he was on time with these. ${ }^{101}$ It is telling that the contract specified that Killian had to "pay for all beverages so furnished him once each week, making settlement in full for all purchase made the week previous." 102 The Harvard Brewing Company made explicit in their brief that the reason they took Killian to court was that he stopped making weekly payments for product ordered, not that he had not made loan repayments. This evidence forces a reconceptualization not only of the brewery industry in Boston at the turn of the century, but also of the factors in the channel structure that inhibited or promoted complete forward vertical integration. Most studies suggest that saloonkeepers were workers who had little or no capital of their own, ${ }^{103}$ and their need for loans was a crucial part of the Boston brewing channel. While there is evidence of their solidarity with the

100. Wade, Swaminathan, and Saxon, "Normative and Resource Flow Consequences," 906.

101. The plaintiff's substitute declaration, contained in the defendant's brief, specifies that Killian "has paid to the defendant various sums of money as interest on said loan." This suggests that Killian had not made the regular repayments on principal that the contract had originally specified. Harvard Brewing Company v. Lawrence J. Killian, 222 Supreme Judicial Court for the Commonwealth of Massachusetts (March 1915), Brief for Respondent, at 37 (Massachusetts Supreme Judicial Court, Massachusetts Reports).

102. Ibid.

103. See, especially, Duis, Saloon; Powers, Faces Along the Bar; Rothbart, "Ethnic Saloon.” Roy Rosenzweig, writing about the nearby Massachusetts city of Worchester, has also noted that the occupational world of the saloonkeeper "was not particularly distinct from that of the blue-collar worker," and saloonkeepers' economic standing was only marginally better. See Rosenzweig, Eight Hours for What We Will, 52. 
brewery workers (made clear by their opposition to scab workers), ultimately the saloonkeepers' ties to capital made their solidarity contingent. Just as tightness of labor markets means higher wages for workers, it seems reasonable to conclude that the constriction of distributive channels into bottlenecks-here by legislation, although other causes were possible-meant the possibility of the extraction of better terms from wholesalers on the part of distributors. Of course, this availability of loans on very easy terms precluded the development of the kind of "laborite" democracy that Helena Flam suggests can emerge in which skilled workers (or at least those with relatively high wages, a category to which at least a few saloonkeepers might have belonged) are well integrated into local real estate and credit markets. ${ }^{104}$

The availability of easy credit from breweries was perhaps also an inadvertent contributing factor to the power of the prohibition movement. Despite a somewhat sympathetic report in 1905 by Boston researchers on the positive role of saloonkeepers in the working-class community, ${ }^{105}$ the saloon was the focal point of the temperance opposition. Middle-class observers at the turn of the century asserted that saloonkeepers sold liquor to minors, kept their doors open until late, and were open on Sundays because the law of demand was "almost the only law that they will obey, and it is this law that we must face and deal with unflinchingly." 106 The lack of integration in local financial markets perhaps was one of the elements that prevented saloonkeepers from being seen as upstanding citizens. Their perceived desperation for money led the public to believe that saloonkeepers allowed vice of all sorts to go on in their establishments in order to be able to repay their debts. As noted above, Ogle (who shares these suspicions of the turn-of-the-century prohibitionists) suggests that only by running a combination of a gambling den, brothel, and saloon could a saloonkeeper manage to pay the rent. While the examination of these documents suggests otherwise, the prohibitionists were ultimately able to convince the American public of the evil of saloons. The threat of total prohibition-very real throughout the late nineteenth century, given its occurrence in the nearby state of Maine and the "creeping prohibition" that the so-called local option allowed for-perhaps also contributed to the form of the tied system in Boston. Rather than invest capital in retail outlets that might not be allowed to retail the product, Boston brewers preferred the loan-tie system and its lesser exposure to the losses that Prohibition would mean.

104. Flam, "Democracy in Debt."

105. Committee of Fifty for the Investigation of the Liquor Problem, Liquor Problem.

106. Melendy, "Saloon in Chicago," 292. 
There are other stories that could be told from the Haffenreffer Records, including the managers' change in status (from owners to what Rudi Batzell calls "functionaries of capital"), ${ }^{107}$ their interest and investment in new technologies, the presence of women in the work involved with saloons, financing, and the relationship between the city's urban market and Boston's hinterland. There is evidence for these discussions in the Haffenreffer Records, but they were beyond the scope of this paper. However, the Heffenreffer Records could provide a starting point for further research on these webs of capital. The brewery markets in both the United States and the United Kingdom are still regulated today, so research on the paths that led to the present regulations might provide a way forward.

\section{Bibliography of Works Cited}

\section{Books}

Bain, Joe Staten. Industrial Organization. New York: Wiley, 1959.

Behr, Edward. Prohibition: Thirteen Years That Changed America. New York: Arcade Publishing, 2011.

Chandler, Alfred Dupont. The Visible Hand: The Managerial Revolution in American Business. Cambridge, MA: Belknap Press, 1977.

Downard, William L. Dictionary of the History of the American Brewing and Distilling Industries. Westport, CT: Greenwood Press, 1980.

Duis, Perry. The Saloon: Public Drinking in Chicago and Boston, 1880-1920. Urbana: University of Illinois Press, 1983.

Friedrich, Manfred, and Donald Bull. The Register of United States Breweries, 1876-1976. Stamford, CT: Donald Bull, 1976.

Gourvish, T. R., and R. G. Wilson. The British Brewing Industry, 1830-1980. New York: Cambridge University Press, 1994.

Gutzke, David W. Protecting the Pub: Brewers and Publicans against Temperance. London: Boydell Press, 1989.

Hawkins, Kevin H., and C. L. Pass. The Brewing Industry: A Study in Industrial Organisation and Public Policy. London: Heinemann, 1979.

McGirr, Lisa. The War on Alcohol: Prohibition and the Rise of the American State. New York: W. W. Norton, 2015.

Mittelman, Amy. Brewing Battles: A History of American Beer. New York: Algora Publishing, 2008.

Powers, Madelon. Faces Along the Bar: Lore and Order in the Workingman's Saloon, 1870-1920. Chicago: University of Chicago Press, 1999.

Ogle, Maureen. Ambitious Brew: The Story of American Beer. New York: Harcourt, 2006.

Richmond, Lesley, and Alison Turton. The Brewing Industry: A Guide to Historical Records. New York: Manchester University Press, 1990.

107. Batzell, "Reconstructing Global Capitalism." 
Rosenzweig, Roy. Eight Hours for What We Will: Workers and Leisure in an Industrial City, 1870-1920. New York: Cambridge University Press, 1983.

Rush, Benjamin. An Inquiry into the Effects of Spirituous Liquors on the Human Body: To Which Is Added, a Moral and Physical Thermometer. Boston: Thomas and Andrews, 1790.

Scherer, F. M., and David Ross. Industrial Market Structure and Economic Performance, 3rd ed. Boston: Houghton Mifflin, 1990.

Schlüter, Hermann. The Brewing Industry and the Brewery Workers' Movement in America. International Union of United Brewery Workmen of America, 1910.

Schorow, Stephanie. Drinking Boston: A History of the City and Its Spirits. Wellesley, MA: Union Park Press, 2012.

Swinnen, Johan F. M. ed. The Economics of Beer. New York: Oxford University Press, 2011.

Thomann, Gallus. Documentary History of the United States Brewers' Association: With a Sketch of Ancient Brewers' Gilds, Modern Brewers' Associations, Scientific Stations and Schools, Publications, Laws and Statistics Relating to Brewing Throughout the World, Brewers in Public Life, \&c. Vol. 1-2. New York: The United States Brewers' Association, 1896.

Tremblay, Victor J., and Carol Horton Tremblay. The U.S. Brewing Industry: Data and Economic Analysis. Cambridge, MA: MIT, 2009.

Trouillot, Michel-Rolph. Silencing the Past: Power and the Production of History. Boston: Beacon Press, 1995.

von Hoffman, Alexander. Local Attachments: The Making of an American Urban Neighborhood, 1850 to 1920. Baltimore, MD: Johns Hopkins University Press, 1994.

\section{Articles, Reports, and Chapters in Books}

Appel, Susan. "Building Milwaukee’s Breweries: Pre-Prohibition Brewery Architecture in the Cream City." Wisconsin Magazine of History 78, no. 3 (Spring 1995): 162-199.

Bousé, Derek. "Restoring the Photographed Past." Public Historian 24, no. 2 (May 2002): 9-40.

Busch, Jane. "Second Time Around: A Look at Bottle Reuse." Historical Archaeology 21, no. 1 (1987): 67-80.

City Council of Boston. Reports of Proceedings of the City Council of Boston for the Year Commencing January 2, 1905, and Ending December 30, 1905. Boston: Municipal Printing Office, 1906.

Committee of Fifty for the Investigation of the Liquor Problem, The. The Liquor Problem: A Summary of Investigations. Boston: Houghton, Mifflin, 1905.

Crompton, Gerald. “Well-Intentioned Meddling': The Beer Orders and the British Brewing Industry.” In The Dynamics of the International Brewing Industry since 1800, edited by R. G. Wilson and T. R. Gourvish, 160-175. London: Routledge, 1998.

Flam, Helena. "Democracy in Debt: Credit and Politics in Paterson, NJ, 18901930." Journal of Social History 18, no. 3 (1985): 439-462. 
Fox, Hugh F. "The Prosperity of the Brewing Industry." Annals of the American Academy of Political and Social Science 34, no. 3 (1909): 47-57.

Gokhale, Jayendra, and Victor J. Tremblay. "Competition and Price Wars in the U.S. Brewing Industry.” Journal of Wine Economics 7, no. 2 (November 2012): 226-240.

Hatten, Kenneth J., Dan E. Schendel, and Arnold C. Cooper. "A Strategic Model of the U. S. Brewing Industry: 1952-1971." Academy of Management Journal 21, no. 4 (December 1, 1978): 592-610.

Hull-Walski, Deborah A., and Frank L. Walski. "There's Trouble a-Brewin': The Brewing and Bottling Industries at Harpers Ferry, West Virginia." Historical Archaeology 1994, 106-121.

Iversen, Martin, and Andrew Arnold. "Carlsberg: From Exporter to an Integrated Multinational Enterprise.” Brewery History no. 131 (2009): 51-62.

Iwasaki, Natsuko, Barry J. Seldon, and Victor J. Tremblay. "Brewing Wars of Attrition for Profit (and Concentration)." Review of Industrial Organization 33, no. 4 (October 19, 2008): 263-279.

Knox, D. M. "The Development of the Tied House System in London." Oxford Economic Papers, New Series 10, no. 1 (February 1958): 66-83.

Lafontaine, Francine, and Margaret E. Slade. "Transaction Cost Economics and Vertical Market Restrictions-Evidence." Antitrust Bulletin 57, no. 3 (2012): 587-611.

Massachusetts Supreme Judicial Court. Massachusetts Reports: Decisions of the Supreme Judicial Court of Massachusetts. Boston: Little, Brown, and Company, 1894.

McGahan, A. M. "The Emergence of the National Brewing Oligopoly: Competition in the American Market, 1933-1958." Business History Review 65, no. 2 (Summer 1991): 229-284.

Melendy, Royal. "The Saloon in Chicago." American Journal of Sociology 6, no. 3 (November 1900): 289-306.

Mittelman, Amy. "The American Brewing Industry since Repeal: Large and Small Brewers." Journal of the Brewery History Society 141 (2011): $2-4$.

Mutch, Alistair. "Allied Breweries and the Development of the Area Manager in British Brewing, 1950-1984." Enterprise \& Society 7, no. 2 (May 18, 2006): 353-379.

—. "Shaping the Public House, 1850-1950: Business Strategies, State Regulation and Social History." Cultural and Social History 1, no. 2 (May 2004): 179-200.

O’Sullivan, Mary A. "Yankee Doodle Went to London: Anglo-American Breweries and the London Securities Market, 1888-92." Economic History Review 68, no. 4 (November 1, 2015): 1365-1387.

Portelli, Alessandro. "What Makes Oral History Different." In The Oral History Reader, 2nd ed., edited by Robert Perks and Alistair Thomson, 32-42. London: Routledge, 2006.

Porter, Michael E. "Towards a Dynamic Theory of Strategy." Strategic Management Journal 12, no. S2 (December 1, 1991): 95-117. 
Powers, Madelon. “The 'Poor Man's Friend': Saloonkeepers, Workers, and the Code of Reciprocity in US Barrooms, 1870-1920." International Labor and Working-Class History 45 (1994): 1-15.

Rothbart, Ron. "The Ethnic Saloon as a Form of Immigrant Enterprise." International Migration Review (1993): 332-358.

Stack, Martin. "Local and Regional Breweries in America's Brewing Industry, 1865 to 1920." Business History Review 74, no. 3 (2000): 435-463.

Stack, Martin, and Myles P. Gartland. "Path Creation, Path Dependency, and Alternative Theories of the Firm." Journal of Economic Issues 37, no. 2 (June 2003): 487-494.

- "The Repeal of Prohibition and the Resurgence of the National Breweries: Productive Efficiency or Path Creation?" Management Decision 43, no. 3 (March 1, 2005): 420-32.

U.S. Bureau of the Census. Fourteenth Census of the United States. Population, D1-578, Ward 21, Boston, Suffolk County, Massachusetts. Washington, DC: Government Printing Office, 1920.

- Twelfth Census of the United States. Schedule 1-Population, 116 A, 1535, Ward 24, Boston, Suffolk County, Massachusetts. Washington, DC: Government Printing Office, 1900.

Wade, James B., Anand Swaminathan, and Michael Scott Saxon. "Normative and Resource Flow Consequences of Local Regulations in the American Brewing Industry, 1845-1918.” Administrative Science Quarterly (1998): 905-935.

Watson, Katherine. "Banks and Industrial Finance: The Experience of Brewers, 1880-1913." Economic History Review 49, no. 1 (February 1996): 58-81.

Williamson, Oliver E. "Transaction Cost Economics: The Natural Progression." American Economic Review 100, no. 3 (June 2010): 673-90.

Newspapers

Boston Daily Globe

McClure's Magazine

\section{Dissertations}

Batzell, Rudi. "Reconstructing Global Capitalism: Class, Corporations and the Rise of Welfare States in the US and UK, 1870-1930." PhD dissertation, Harvard University, unpublished.

Archives

Harvard Baker Business Library, Boston, MA.

Historic New England, Boston, MA.

Jamaica Plain Historical Society, Jamaica Plain, MA. 